DOI https://doi.org/10.36059/978-966-397-207-7/30-56

\title{
SPECIFIC FEATURES OF STATE FORMATION AND LEGAL POLICY OF PRESIDENT D. TRUMP
}

\section{Kalashnikov V. M.}

\section{INTRODUCTION}

It is known that at the beginning of this century the phenomenon, which is commonly known as "globalization", entered a period of a crisis. This crisis, the reasons for which existed in globalization from the very beginning, has economic, socio-cultural and geo-cultural aspects. The first group of causes was laid down in the geo-cultural economic model, which has its own special system of values and economic imperatives imposed by the Western civilization that is consuming by nature. The second group of causes of the globalization crisis is the mismatch of the goals, such as spreading freedom and democracy, commodity prosperity and consumer satisfaction, which were claimed by the Western civilization elite, and actual opportunities for their implementation. US President D. Trump was the first among the majority of the American elite to understand these realities, having taken into account that the gross domestic product of America today makes up only a quarter of the world's GDP, whereas it made up $40 \%$ in 1960.

President D. Trump and the people holding the same view can not put up with the new realities in the world market development, which demonstrate the fall of American hegemony. That is why there started such transformations of the American economy, which are considered by many politicians and scientists of the Western countries to be the repetition and development of the "New course" of the USA President F.D. Roosevelt. Indeed, Trump's reforms signify a break-up with the traditional policy of the American state, not only in the economic sphere, but also in all spheres of public life of the leading country in the world community.

A state is a multi-faceted phenomenon, which became an integral part of society as early as six thousand years ago. Only it performs various regulatory functions in the society, actively influencing the 
formation of new social structures and spiritual life of people. In this regard, the task of establishing the limits of the state interference in the processes that are inherent in social life is important in order to use predominantly the positive aspects of such influence. And this interference is a state and legal policy of a particular country.

Nowadays, in the scientific literature there are different interpretations of the notion of "politics". Based on the achievements of the scientific research of the thinkers of the past in the field of comprehension of the phenomenon of a state and legal politics, national scientists must come to understand that politics is also the art of the possible, the art of compromises, and the art of agreement of the desired and objectively achievable. Politics finishes beyond the boundaries of the possible, giving way to subjectivism, voluntarism, and often, to adventure. Therefore, the notion of "politics" is used to refer to deliberately organized activities, necessary and expedient within a certain period. As a rule, it is the activity of the state governing bodies and state administration, parties and public associations. Hence, it follows that the politics, in a broad sense, should be defined as an interaction of people, groups, nations, and classes through the implementation of state power. At the same time, we are dealing with legal policy in the case when a state relies on the law in the process of power regulation.

The state regulates all major areas of vital activities of the society. However, if they are intertwined and become interdependent, the policy regulating these spheres is a single whole. This is what has been inherent in the history of the state and the law of the USA since 1607 , when the British colony of Virginia - a center of the future superpower - emerged. That was the first element of the grandiose structure, the early America, which became the only state in the world history to be the first to develop in the capitalist way.

It was then that the principles of the legal policy of the American society were perfectly stated by a professional lawyer, the second Governor of the Massachusetts colony, J. Winthrop. In the document entitled "A Model of Christian Charity" (1630), he put forward such new for that time concepts as "natural law" and "charity agreement". However, in practice, Winthrop took care only of protecting the right to private property from criminal encroachment of the poorest. $\mathrm{He}$ was guided by the belief in the eternity of social inequality, having 
declared the following: "GOD ALMIGHTY in his most holy and wise providence, hath so disposed of the condition of' mankind, as in all times some must be rich, some poor, some high and eminent in power and dignity; others mean and in submission"1. And such approaches to the solution of complex social problems for a long time met the interests of the dominant classes of the population of the colonial America. This is what became the symbol of faith of the founders of independent America.

The well-known American scientist, A. Schlesinger, Jr., the author of the monograph "The Cycles of American History", pointed out that the essence of the state policy of his country should be considered through the prism of the messianic ideology. He also wrote: "the struggle between capitalist values - the inviolability of private property, the maximization of profits, the cult of the free market, the survival of the strongest - and democratic values - of equality, freedom, social responsibility and general welfare continues in America. Therefore, in his opinion, the great interest in the United States is the private interest of any citizen of the country-leader of the world community, because in America, capitalism includes democracy, and democracy is capitalism"2.

L. Harts in his research "Liberal tradition in America" developed the ideas of Schlesinger, Jr. He pointed out the following: "If America is a country of eccentric embodiment of liberalism, then the peoples of the whole world are not tied to its hope to save all the best that it has presented to the world"3.

Thus, it is obvious that the USA have a solid ideological foundation of the legal policy, which has been generated for four centuries. That is why American ideology, which is an effective means of influencing the mass public consciousness, has always relied on historical examples when it comes to any problem of state building. This instrument was particularly well used by the American

${ }^{1}$ Foundations of Colonial America; a Documentary History : in 3 vols. / ed. by W. K. Kavenagh. - N. Y.: Chelsea House Publishers, 1973. - Vol. 1. - P. 45-49.

${ }^{2}$ Schlesinger A.M. The Cycles of American History. - N.Y.: Houghton Mifflin Harcourt, 1999. - P. 34.

${ }^{3}$ Hartz L. The Liberal Tradition in America. - Eugene; Oregon: Harvest Books, 1991. - P. 5. 
presidents who received professional legal education. They included T. Jefferson, A. Lincoln, F. D. Roosevelt, H. Truman, J. Kennedy, R. Nixon, B. Clinton and B. Obama. Therefore, it is not surprising that even a professional land surveyor and commander J. Washington who chaired the Philadelphia constitutional convent, made it possible for the provisions on certain features of American legal ideology to be included in the Constitution of the USA ${ }^{4}$.

In the USA of modern times, there is a revival of the ideological directions of the "golden age" which became a thing of the past in the last century. Obviously, America is trying to "restore to life" on the basis of returning to "virtual" rights and morale of the USA past. Current President D. Trump continues to implement the wills of the authors of the American Constitution.

In scientific literature, there are different interpretations of the notion "policy". In some cases, it is used to denote the procedure for making governmental power-regulatory decisions. In other cases, this notion is used to refer to deliberately organized activities, which is necessary and expedient within certain time.

Formation of the legal policy is an objective necessity in a democratic state, where the rule of law prevails. The managerial function of law, the role and significance of legal awareness are steadily increasing and becoming stronger, and agreement principles of legal regulation are expanding, which also proves the actualization of issues of legal policy. The influence of politics on the law is permanently manifested in public law, which reflects the specific features of the interaction of the state with other entities of public life.

All entities of political and legal life are involved in the formation and implementation of the legal policy to a greater or lesser extent. This is clearly reflected in functioning of the state bodies of democratic and legal world countries headed by the United States, whose experience of the historical development of state and legal policy is an example for resolving the pressing problems of the development of society in Ukraine.

${ }^{4}$ American Philosophical Society, Library. Weedon George Henry (1730-1790), General Military Correspondence and Other Materials. - № 131, 139. 


\section{Main features of D. Trump's foreign policy}

The Universal Declaration of Human Rights is the first global expression of the integral rights of all people. Composed by representatives of many countries, where different legal and cultural traditions existed and still exist, it was proclaimed by the United Nations General Assembly in Paris on December 10, 1948 as the only standard for the protection of human rights for all peoples. Academician V. Koretsky, a native of the city of Dnipro, was among the creators of the text of the Universal Declaration of Human Rights. Moreover, he became the author of the first article of the Declaration: "All human beings are born free and equal in dignity and rights. They are endowed with reason and conscience and should act towards one another in a spirit of brotherhood"5. Only this first article was voted for without objections by all members of the UNO Commission.

It is known that the universal standards of human rights that were first enshrined in the Universal Declaration of Human Rights and then reflected in the International Covenant on Civil and Political Rights and the International Covenant on Economic, Social and Cultural Rights, are widely used in the world not only in peaceful times, but also during armed conflicts. It is not accidental that E. Roosevelt, an American public figure, the wife of US President Franklin Delano Roosevelt, called it the Great Charter the freedoms for all humanity, because its provisions are universal for all countries of the world .

Unfortunately, not everything is so "smooth" with the American experience in protecting human rights, which is embodied in the practice of US state formation led by their presidents, starting with G. Truman. Their policy is aimed at the formation, development and preservation of common civilized values in accordance with the "American way of life". And President D. Trump, who believes that the Universal Declaration of Human Rights is not needed for

5 Universal Declaration of Human Rights. United Nations // URL: https://www.un.org/en/udhrbook/pdf/udhr_booklet_en_web.pdf

${ }^{6}$ Glendon M.A. A World Made New: Eleanor Roosevelt and the Universal Declaration of Human Rights. - N.Y.: Random House Trade Paperbacks, 2001. P. 4-5. 
America, as this country has its own special system of values, has recently reminded the world about it.

Undoubtedly, the United States, as the leader of the world community, set certain standards of the humanitarian policy for the entire civilized mankind, however, only a part of these standards in the field of human rights is applied in the United States. This approach to the interaction of the national law of the United States with the system of international law dates back to the time when this country was gaining sovereignty as a result of the victory in the war for independence against the British colonial empire. At the dawn of American statehood, the "Founding Fathers" of the United States had to take into account the reaction of the European countries to American criminal justice proceedings with a foreign element. Therefore, the Act on the Judiciary of 1789 refers to the fact that one of the sources of criminal procedural law should be an international legal tradition ${ }^{7}$. However, the dogma, according to which the resolution of all disputed problems should rely only on the national law, is much more important for the implementation of not only legal proceedings, but also for any other legal agreements affecting the rights and freedoms of the citizens of the United States ${ }^{8}$.

The specific interest to the international legal traditions in the area of defending human rights and freedoms is constantly heated by the resolutions of the Supreme Court of the USA. This body of the highest state power was previously supposed to offer explanations as for how to use the sources of the international law in order to implement the American humanitarian policy. In this case, the law priests in the USA always referred in their decisions to the impact of the well-known research of E. de Wattel "The Right of the Nations".

Following the example of the "Founding Fathers", the elite of the country - leader of the world community originally supported the Universal Declaration of Human Rights. However, soon after, America began to show the signs of opposition to the international

7 Stacy L., Gardiner Ch.L. Criminal Justice Policy. - 2013 / [Text]. - URL: https://play.google.com/store/books/details/Stacy_L_Mallicoat_Criminal_Justice_ Policy?id=nhlzAwAAQBAJ

${ }^{8}$ The Judiciary Act of 1789. - URL: http: //www. constitution.org/uslaw/ judiciary_1789.htm 
system of human rights protection. One of the reasons for this was that during the Cold War, the United States tried not to give its ideological enemies the opportunity to criticize their internal humanitarian policy, such as the discrimination of racial minorities in the form of the laws of Jim Crow. Therefore, the US government did not want to change the discriminatory racial policy as a result of ratification of an international treaty.

It should be emphasized that when the United States ratify the human rights treaty, they almost always add to it a declaration of circumstances that would prevent the protection of certain rights of this kind on their territory. In the US law, two types of warnings for treaties were established. Firstly, the treaty may not "be selfimplemented", because a special legislation is needed to implement it in the judicial institutions of America, which Congress is very reluctant to have.

Another warning is called "Restrictions to the scope of the treaty". This means that the United States have the right to be guided only by their own legal framework in respect of the fulfillment of the terms of the treaty, since they have already settled this problem in the Bill of Rights. On this basis, the United States insist that they will not fulfill any part of the treaty, if its content contradicts the American Constitution?.

America always kept telling the outside world, that many of the rights set forth in the Constitution are equivalent to the rights enshrined in the Universal Declaration of Human Rights and some other pacts, in which, the need for non-changeable protection of human rights and freedoms throughout the world is proclaimed on behalf of the international community. In addition, American propagandists draw the attention of the world community to the fact that the US Supreme Court has determined the fundamental rights that are not explicitly mentioned in the Constitution, such as the presumption of innocence in the criminal process and the freedom of movement. The US Congress also passes the laws that protect constitutional rights and provide protection for victims of human rights violations, when litigation may be too expensive or complex.

\footnotetext{
${ }^{9}$ Human Rights. - URL: https: // www.state.gov/j/drl/hr/
} 
The most important of these national laws are those that prohibit discrimination, including discrimination on the grounds of race, sex, religion or disability ${ }^{10}$.

Thus, the United States believe that the US Constitution provided some protection for civil and political rights, so it is not necessary for America to turn to the economic, social and cultural rights guaranteed by the Universal Declaration of Human Rights. That is why the US government has not yet ratified important treaties related to human rights. As far as the humanitarian policy of the incumbent US President D. Trump is concerned, he regularly criticizes the United Nations for inefficient work and excessive expenditures.

From now on, the entire Western world is in a state of despair, as the leaders of the allies consider the Human Rights Council to be a tool for global governance, through which they have succeeded in promoting their own values as a matrix for all countries of the world. Washington's decision to withdraw from the Human Rights Council is a striking example of rejection of the concept of multilateralism in international relations ${ }^{11}$. D. Trump finally chose a nationally oriented American strategy based on bilateral agreements, and he agrees to work only with those foreign leaders, with whom it is beneficial to have some kind of relationship. That is why the Universal Human Rights Declaration is not directly related to the United States, and this is very sad for the entire civilized world. Against this background, D. Trump "solves" the most important problems of protecting human rights in his own country somehow unnoticeably. The "Indian problem" still remains among these problems since the proclamation of US independence from the United Kingdom.

It is known that the founders of the United States took care that the land of aborigines, captured by America, should be formalized as a "legitimate prize" for the civilized American nation that "defended

10 Human Rights and United States Law. - URL: http:// www.theadvocatesforhumanrights.org/human_rights_and_the_united_states

${ }^{11}$ U.S. Withdraws from U.N. Human Rights Council Over Perceived Bias Against Israel. - URL: https://www. washingtonpost.com/world/national-security/usexpected-to-back-away-from-un-human-rights-council/2018/06/19/ a49c2d0c-733c11e8-b4b7-308400242c2e_story. html?utm_term=.358873b15730 
itself from savages"12. The current president is trying to sanctify his own aboriginal policy, which is driven by the warnings and the cult of the Founding Fathers. Moreover, at the height of the struggle with political opponents, the head of the American state uses unacceptable methods to justify his Indian policy. That is why the National Congress of American Indians (NCAI), the oldest, the largest and the most representative organization of American Indians, recently condemned the words of D. Trump that the ancestors of the Indians themselves are to blame for the fact that their uprisings in WoundedKnee and Little Big Horng were suppressed by US troops: "You can not attack political opponents, as it was against Senator Elizabeth Warren. We condemn in the strongest possible terms the casual and callous use of these events as part of a political attack. Hundreds of Lakota, Cheyenne, and Arapaho people lost their lives at the hands of the invading U.S. Army during these events, and their memories should not be desecrated as a rhetorical punch line"13.

Thus, after the "humanitarian transformations" of D.Trump, the entire Western world is in a state of despair, as its leaders consider the Human Rights Council to be a tool for global governance, through which they have succeeded in promoting their own values as a matrix for all countries of the world. Not long ago, the USA were the main participant of the global policy, but Washington's decision to withdraw from the Human Rights Council is a striking example of rejection of the concept of multilateralism in international relation. A new blow to the western community was hit by D. Trump's economic policy, the legal principles of which deserve closer attention.

It is known that, in the opinion of the political leaders of the leading countries of the world, the foreign economic policy of the

12 American Philosophical Society, Library. Calendar of the Papers of Benjamin Franklin. - Vol. 1. - Film 54. - Reel 43, 107, 113; American Philosophical Society, Library. Presidential Papers Microfilms. Thomas Jefferson Papers. Jeneral Correspondence, 1761-1826. Account Books for the Years 1767-1770. Reel 58, Serie 4; Reel 59, Serie 4-5; Reel 60, Serie 11-12.

13 NCAI Denounces President Trump's Invoking of Wounded Knee Massacre and Battle of Little Bighorn in Political Attack. - URL. - Режим доступу: http://www.ncai.org/news/articles/2019/01/14/ncai-denounces-president-trump-sinvoking-of-wounded-knee-massacre-and-battle-of-little-bighorn-in-political-attack 
American leader may cause damage to the world economy. Therefore, the US Chamber of Commerce, representing the interests of most of the country's business elite, argues that Trump's reforms could lead to a world trade war that will strike a blow to the purse of American consumers. However, Trump, who is believed to be "an elephant in a crockery", is in fact a deeply educated person who can understand the intricacies of the home and foreign policy of the United States, because he got education at the New York Military Academy and the Wharton School of Business, from which he graduated in 1968 with Bachelor's Degree in Economics and specialization in Finance ${ }^{14}$.

It should be noted that none of Trump's biographers pays attention to the fact that the cadets of the Military Academy and students of the Business School are very scrupulously studying home and foreign history. That is why, apparently, Trump attaches much attention to the experience of state building the founders of the United States. He knows that the Founding Fathers of the country-leader of the world community played simultaneously a number of roles throughout their conscious lives, including the following: a planter and slave-owner, an oppressor of white bonded slaves, a merchant of African captives, a smuggler, a pirate, a land speculator, a hard-core bankrupt, a financial fraudster, a money launderer of municipal bodies, a caper (a commercial pirate), an organizer and a participant in the genocide of the Indians of the North America, a sadist, who oppressed his own temporary (whites) and life-long (blacks) slaves, a politician, a religious bigot, a perjurer, etc. ${ }^{15}$. In addition, on the top of the list there is such a notion as a "separatist", that is, a person who betrayed the oath of loyalty to the British monarchy, resulting in his being for a long time in a tumultuous position of a criminal offender, for who a sturdy rope was waiting. That is why Trump realized: with the present heirs of the creators of bourgeois America, who do not imagine the historical process without immediate benefit, one can

14 Duignan B. Donald Trump President of the United States. - URL: https://www.britannica.com/ biography/Donald-Trump

15 Калашников В. М., Малишко В.М. Формування інститутів держави і права в США ранньої доби (1607-1775 роки). Монографія. - К.: Логос, 2015. C. 9 . 
only destroy the country-leader of the world. So, he became a supporter of F.D. Roosevelt with his "new course", due to which America escaped destruction in the 1930s.

In fact, in economy, president-businessman Trump follows the slogan "America comes first" and plans to introduce customs barriers. If his plan is implemented, it will become a significant blow to the global economy, as experts warn. And our country is bound to suffer from it, since there is a rule of profit pursuers: "Nothing personal, only business". Unfortunately, the general public of Ukraine, who are counting on the fact that the United States will save the economy of our country from a decline under conditions of a globalization crisis, are mistaken. There is only one sober view among our compatriots on this matter, stated in the Internet. It goes about the article of O. Kushch "Problems of Indians have nothing to do with the sheriff. Why the United States introduce duties against such countries as Ukraine", which was published in May, 2016.

It is known that the economic policy of any state is an inseparable part of the development of world integration processes. Therefore, the growth of foreign trade relations and scientific and technical cooperation of Ukraine with developed foreign countries, first of all, with the USA, is an important condition for the success of the national foreign policy. Recently, the US really helped us solve the pressing economic problems. The State Statistical Service of Ukraine informed that during 2017, the volume of mutual trade and investments between Ukraine and the USA increased fourfold. However, it's too early to rejoice at this, since D. Trump appeared to have other than $\mathrm{B}$. Obama views on cooperation in the economic field, even with the closest allies of Americans.

It should be remembered that during his election campaign, Trump subjected to devastating criticism the countries that exported to the United States more goods than they imported with the label "made in USA". So, it is not surprising that our country is among the ones, to which Trump decided to make a "gift" in the form of high customs

16 Кущ О. Проблемы индейцев шерифа не волнуют: Зачем США вводят пошлины против таких стран, как Украина. - URL: https:/ 112.ua/ mnenie/problemy-indeycev-sherifa-ne-volnuyut-zachem-ssha-vvodyat-poshlinyprotiv-takih-stran-kak-ukraina-444994.html 
tariffs. In the spring of 2018, the US Trade Representative Office told the whole world that it suspended duty-free trade for 155 product groups, namely: the products of food, light, woodworking industries, machine-building, and electrical appliances ${ }^{17}$. The United States immediately made a decision to protect copyright and related rights from the encroachment on the part of China and other countries. The Americans gave their trading partners 120 days to get ready for the new relationship with the American party. That is why our country also suffered. Recently, a $25 \%$ duty was imposed on steel supplies to the US market, which could affect our manufacturers of pipe and wheel pairs. It is true that the US allowed us to supply food, products of light industry and woodworking, and linen clothing to the US market, but the cost of these supplies in the 2017 amounted to ridiculous 64 million, 2 million, 13 million and 2 million dollars, respectively.

Thus, it is obvious that the United States as the leader of the world community set certain standards in the field of economic policy for the civilized world. However, these standards rely primarily on the America's national law, since the closeness of the American legal system is ensured by the complicated order of the inclusion of international treaties in the system of sources of law. Hence, it follows that the model for the international law implementation, created in the USA, can be characterized as complicated and rigid. It reminds of a multi-stage system of filters, the passage through which serves as a guarantee of "rejection" of those norms of international law that contradict national law. The emergence of such a policy should be attributed to the adoption of the first American constitution, which was called "Articles of the Confederation and the Eternal Union" (1977). This normative act established that the US treasury can be replenished only through imposing the percentage duty on all goods imported into the country. This course was also followed after passing the current Constitution of the US, which reads: "Section 8. 1: The Congress shall have Power To lay and collect Taxes, Duties, Imposts and Excises, to pay the Debts and provide for the common

17 Statement By U.S. Trade Representative Robert Lighthizer on Section 301 Action. - URL: https://ustr.gov/about-us/policy-offices/press-office/press-releases/ 2018/august/state ment-us-trade-representative 
Defence and general Welfare of the United States; but all Duties, Imposts and Excises shall be uniform throughout the United States" ${ }^{18}$.

The US Constitution established that the United States President is the only carrier of executive power that forms and implements the economic policy of this state. No bodies of executive power are mentioned in the US Constitution. In this country, there is no government in the proper sense of the word, but among federal executive bodies, there are structures similar in composition and functions to government-type bodies. These American institutions are united by the notion of "presidential administration", which is entrusted to deal with the organization and implementation of the state customs policy in a centralized way. In exercising his own powers, the leader of the American state issues various legal acts. These include executive orders that regulate many issues of public administration, as well as instructions, directives, rules and regulations that are applied throughout the country and contribute to the implementation of US state economic policy. Thus, the head of the state determines the main directions of economic policy, whereas four-million staff of the federal executive authorities, including customs officers, are involved in the implementation of this policy ${ }^{19}$.

Customs authorities of the US have to perform the following tasks: 1) prohibition of the flow of illegal goods to the United States; 2) collection of customs duties; 3) regulation of the export of American goods; 4) collection of statistical data on import, etc. In addition, the continuous development of the customs service requires constant improvement of the law on its organizational and legal principles ${ }^{20}$. Setting the order in this area of government policy under condition of the globalization crisis became the top priority of the US state policy for D. Trump. He is a businessman who knows well enough that law-abidingness has never been the virtue of American entrepreneurs.

${ }^{18}$ The Constitution of the United States. The Bill of Rights \& All Amendments. URL: https://constitutionus.com

${ }^{19}$ Oliver W.M. The Power to Persuade: Presidential Influence over Congress on Crime Control Policy // Criminal Justice Review. - 2003. - N 28. - P. 113-132.

20 U.S. Code: Title 18. - Crime and Criminal Procedure. - URL: //www/ law/cornell/edu/uscode/text/18. 
President Trump remembers that the main signature under the Declaration of Independence was made by the head of the Continental Congress, the "uncrowned king of pirates and smugglers" D. Hancock (1737-1793). Throughout his life he openly violated the customs legislation not only of England, but also of independent America, proving that smuggling is the most profitable business for entrepreneurs $^{21}$. The descendants of slave traders, pirates and smugglers of the past centuries are not able to break free from this historical experience. This was acknowledged by D. Trump and his team, who announced that they would introduce such home policy that would contribute to the elimination of customs-related crimes within the United States itself through the rapid and severe criminalization of new means of violation of customs legislation. This resulted in the beginning of the process of improving the Code of Law of the United States, which is an official generalization and codification of general and permanent federal laws, first of all, criminal ones $^{22}$.

However, the US still do not have a federal criminal code in its general sense. Under the Act of Congress of June 25, 1948, most of the previously existing legislation was revised, codified and incorporated in the form of a law in the title

18 of the US Code of Laws ${ }^{23}$. However, it is characteristic of the US Code of Law that the rules of criminal law that are included in it are casuistic and descriptive by nature. In addition, this book contains many outdated and even archaic criminal rules that can not contribute to the implementation of the "new state and legal policy" of D. Trump. Nevertheless, the president announced that he would resolutely act in the area of the introduction of new customs tariffs for

${ }^{21}$ Settel A. Pictorial History of the United States Customs Service. - N.Y.: Crown Publications, 1976. - P. 10.

22 Уголовное законодательство зарубежных стран (Англии, США, Франции, Германии, Японии). Сборник законодательных материалов / [Текст] / [под ред. И. Д. Козочкина]. - М.: Зерцало, 1999. - 352 с.

23 U.S. Code: Table Of Contents. Legal Information Institute. - URL: https://www.law.cornell.edu/uscode/text 
US opponents and criminalization of customs crimes committed inside America itself ${ }^{24}$.

It should be noted that Trump's legal foreign economic policy is Article 232 of the Trade Extension Act of 1962, which under certain circumstances allows the president to set custom tariffs based on the recommendation of the US Trade Secretary. This law was rarely used by Trump's predecessors, and therefore on March 22, 2018, he signed a memorandum that instructed the US Trade Representative to apply tariffs for Chinese goods worth $\$ 50$ billion. Trump noted that the tariffs would be imposed because of the theft of intellectual property of the United States by the Chinese and announced that he planned such tariffs for import of foreign countries, which would help America return to the status of the world hegemon ${ }^{25}$. This course of Trump led to the announcement of the trade war to China in the official periodicals "Federal Register" and "The Code of Federal Regulations" ${ }^{26}$. In response, the Ministry of Commerce of the People's Republic of China announced the plans to introduce its own high tariffs for 128 US products. And this terrified American manufacturers. They appeal to the limitation of the action of the Federal criminal legislation in the event when they are forced to violate customs legislation. However, the Trump administration insists on increasing sanctions for customs and tax offenses to reduce the scope of applying the administrative sanctions and to extend the scope of applying the criminal sanctions ${ }^{27}$.

The Government of D. Trump insists on the application of criminal penalties under the statutes, which were previously not used in judicial practice in the condemnation of people who committed

${ }^{24}$ Model Penal Code. The American Law Institution. 6th Annual Meeting. May 20-22, 2019. - Washington, DC/ [Text]. - URL: https://www.ali.org/ publications/show/model-penal-code/

${ }^{25}$ President Donald Trump Hit Chinese Smports to the US with Massive Tariffs on Thursday. - URL: https:// www.businessinsider.com/trump-tariffs-what-is-atariff-meaning-for-prices-consu mer-2018-3

${ }^{26}$ Electronic Code of Federal Regulations. - URL: http://www.ecfr. gov/cgibin/ECFR?page=browse.

${ }^{27}$ Rocha A.F. And Up to Twenty Years in Prison: The Criminalization of US Customs Violations - July 2015 [A.F. Rocha, D. Barclay, D. Bond, D. Lew, G. Spak, L. Winer]. - P. 10. - URL: https: //wwwgfintegrity.org/wp-content/ uploads/2015/ 07/Criminalization-of-US.29. 
customs and tax crimes. In this case, we are talking about a conspiracy for the purpose of non-payment of customs duties (18 U.S.C § 371), laundering the money obtained as a result of committing customs crimes (18 U.S.C $\S \S 1956$, 1957), smuggling (18 U.S.C $\S 545$ ), assistance and complicity in customs-related criminal offenses (18 U.S.C $\S 2$ ), mail fraud (18 U.S.C $\S \S 1341$, 1343) and fake declarations of the goods imported into the United States (31 U.S.C $\S \S 3729-33)^{28}$.

Under the new historical conditions, America is not able to take care of the global economic interests of the Western countries, and President Trump proceeds from a simple postulate: "Nothing personal, it's just business". That is why the world economic war was launched, one of the manifestations of which is the "new customs policy" of Trump. Its outcome is hard to predict, but there is no other way out for the countryleader of the world community. And this war is accompanied by radical transformations of US financial policy in order to bring them back to the position of the leader of financial market ${ }^{29}$.

\section{2. "New financial policy" of president Trump}

It is common to call the socio-economic model of a society, which is prevalent today in most countries of the world, capitalism. The official ideological machinery of the capitalist society persuades everybody that the political system suitable for such a society is called "democracy". In fact, it is the power of the richest elite, capitalist oligarchs, for who the term "plutocracy" was introduced in the textbooks on political science ${ }^{30}$.

${ }^{28}$ Report of the Subcommittee on Criminal Justice on Recodification of Federal Criminal Law. Subcommittee on Criminal Justice of the Committee on the Judiciary, House of Representatives. Ninety-fifth Congress, Second Session. - Wash.: U.S. Government. Print. Off., 1979. - P. 11.

${ }^{29}$ Brown M. The Criminalization of Import Violations by Customs Authorities. P. 21-22. - URL: https: //www.mayerbrown.com/public_docs/07-13-11_Global Strategies-Criminalization_of_Import.pdfp.

30 Катасонов В.Ю. Диктатура банкократии. Оргпреступность фанансовобанковского мира. Как противостоять финансовой кабале. - 2014. - URL: https://www.ozon.ru/context/detail/id/2765 5786/ 
According to the researchers, the plutocrats, being energetic "combiners", creators of the pyramids, the first of which was created by the founder of the first Bank of America R. Morris, put their own selfish interests in the forefront ${ }^{31}$. Therefore, before the beginning of the presidential term of D. Trump, the US dollar had served as currency of not only the United States, but also for the rest of the world ${ }^{32}$. The dollar was the dominant equivalent of exchange in cross-border operations and the most popular asset used by central banks and governments to create financial reserves. However, this currency began to lose brilliance even before the current problems with US debt arose. Its share in the global reserves of central banks has decreased from $70 \%$ to $60 \%$ for the last 10 years.

In the market economy, there exists the state regulation of the financial relations, which is a system of legislative, executive and supervisory measures implemented by authorized state institutions in order to stabilize the socio-economic system and its adaptation to changes in the life of the society and the state. A periodic change or correction of the mechanisms of financial regulation of the economy is associated with periodic growth of non-equilibrium, instability and uncontrollability of economic processes ${ }^{33}$. The role of the state as an organizing principle in the integrated process of social evolution is intensified exactly during the periods of increasing instability of the system and changing the modes of interaction between the state and the economy. This requires the prevention of the devastating consequences of these processes, which is what the team of President D. Trump is

${ }^{31}$ Calabria M.A. Monetary History and Policy. A Reading List [M.A. Calabria, J.A. Dorn, G. Selgin]. - URL: https://www.cato.org/research/ banking/rl-monetarypolicy.html

32 The U.S. Financial Regulatory System. - URL:https://www.cfr.org/ backgrounder/us-financial-regulatory-system

33 Долан Э. Дж., Кэмпбелл Р. Дж. Деньги, банки и денежно-кредитная политика: [пер. с англ.]. - СПб.: АОЗТ «Литера плюс», 1994. - URL: http://www.bibliotekar.ru /bank-8/ 
engaged in, conducting important economic, political, social and legal reforms ${ }^{34}$.

The real political and legal life demonstrates the inextricable link between financial relations and politics, which requires an active financial and legal policy as an optimal model of their interaction. American lawyers are convinced that the Great Depression should be considered a large laboratory to study this phenomenon (1929-1938), because it was then that financial and legal policies served the interests of constantly changing political forces, rather than all the people $^{35}$. This is clearly traced in subjectivity and the desire of political forces to satisfy the interests of individual regions or power structures $^{36}$.

The state financial activities of the administration involve the performance of its functions for the systematic development, distribution and the use of financial resources for the purposes of economic and social development and strengthening defense and security of countries ${ }^{37}$. The main organizational and legal peculiarities of financial activity are: 1) it differs from other spheres of the state activity by inter-sectoral content, since the accumulation and distribution of financial resources affects all authorities and administrations, as well as corporations, organizations and institutions involved in their implementation; 2) budget funds for the main spheres of life of the state or entities of the American federation are distributed by the representative bodies; 3) The scope of financial

${ }^{34}$ What Impact Does Government Regulation Have on the Financial Services sector? Updated Feb 5, 2018. - URL: https://www. investopedia.com/ask/answers/ 030315/what-impact-does-government-regulation-have-financial-services-sector.asp \

${ }^{35}$ Wildavsky A. The Politics of the Budgetary Process. - Boston; Toronto: Little Brown Co., 1964. - P. VI-VII.

${ }^{36}$ Glaeser E.L., Goldin C.D. Corruption and Reform: Lessons from America's Economic History. - Chicago: University of Chicago Press. - URL: http://bookre.org/reader?file $=711219$

${ }^{37}$ GC18/1: Proposed Guidance on Financial Crime Systems and Controls: Insider Dealing and Market Manipulation. Guidance consultations. First published: 27/03/2018. Last updated: 27/03/2018. - URL: https://www.fca.org.uk/ publications/guidance-consultations/gc18-1-proposed-guidance-financial-crimesystems-and-controls-insider-dealing 
activity refers to the behavior of both federal bodies and entities of the American federation and local self-governing bodies ${ }^{38}$.

The specific feature of the US institutional policy arranging the activities related to the maximum possible decentralization of the banking system, which led to the fact that the US, does not actually have a central bank in its traditional sense. Its functions were shared by the Treasury (issuance of treasury bills) and the Council of Governing FRS, which interacts with those state banks that perform the functions of the central bank for the entities of the American federation.

In accordance with the law on the FRS, the central bank should ensure maximum employment, price stability and moderate long-term interest rates on loans in the United States, but specific figures in the legislation are not written and given to the discretion of its management. A similar integrated mandate distinguishes the Federal Reserve from central banks of other developed countries, whose task is usually to maintain stable prices. The FRS mission is complicated by the need to take care of economic growth, which is associated with low unemployment and low loan rates. The complexity of this mission urges the American central bank to keep a more active position when implementing the monetary policy ${ }^{39}$.

The Fed traditionally relied on three tools of the monetary policy: 1. The main tool of the Fed policy is opening market operations on sale or purchase of US securities. 2. The Fed may also change the reserve requirements, which indicate what part of clients' deposits (primarily check accounts) should be kept by banks as cash in a repository or as a deposit at the Fed. 3. Finally, the Fed can change the two interest rates it controls directly, and these interest rates affect market rates - the rate it pays to borrowers and the rate it pays to depositors.

38 Federal Policy on Financial Regulation, 2017-2020. - URL: https: // ballotpedia.org/Federal_policy_on_financial_regulation,_2017-2020

${ }^{39}$ Federal Reserve Act. Section 2 A: Monetary policy objectives // The Board of Governors of the Federal Reserve System: website. 2013. - May 23. - URL: http://www.federal reserve.gov/aboutthefed/section2a.htm. 
Politics, of course, is one of the most powerful restrictions on the Fed, and in the current political climate, monetary policy undoubtedly sees the reasons for weakening the negotiations on the bank powers. However, the hawks and other critics of the current Fed seem to be very skilled in using the bank as the political law, without paying particular attention to the details, as the precise scope of the Fed's powers is related to buying assets.

The basis of the financial policy of the US government is financial law as a set of rules that help to resolve conflicts in the financial sector or to establish new rules of behavior of financial entities ${ }^{40}$. All the laws in the United States are arranged in a certain hierarchy, and this system has its own financial law - an independent branch of public law, which contains a set of legal rules governing the social relations that arise in the process of creating, distributing and using financial resources of the state and self-government. Material and procedural norms in the institutions of financial law exist in a certain unity and close interconnection.

It should be noted that the state law, intended for legal regulation of financial relations, is multi-faceted. Such semi-state organizations as the American Law Institute (ALI) and the Uniform Law Commission (ULC) took care of it, trying to coordinate national laws on the legal regulation of financial relations through standard financial laws. However, their attempts appeared to be unsuccessful, and for the harmonization of the federal financial legislation and financial laws of particular states, the judicial interpretation of the "difference" was stipulated by US case law.

In any case, financial and legal policy is a means of control over state finances with the view to strengthening the political power. The fundamentals of the financial policy of the US government are financial law as a set of rules that help to resolve conflicts in the

${ }^{40}$ A Financial System That Creates Economic Opportunities. Banks and Credit Unions. U.S. Department of the Treasury. Report to President Donald J. Trump. Executive Order 13772 on Core Principles for Regulating the United States Financial System. June 2017. - URL: https://www.treasury.gov/press-center/pressreleases/Documents/A\%20Financial\%20System.pdf Financial 
financial sector or to establish new rules of the behavior of financial entities.

Statutory acts adopted by federal agencies in accordance with the "Law on the Improvement of the Administration of Justice by Establishing an Accountable Administrative Procedure" (1946) have legal force, but they must comply with the Constitution and statutory law ${ }^{41}$.

Market economy requires a periodic change or correction of the mechanisms of financial regulation of the economy, associated with the growth of non-equilibrium, instability, and uncontrollability of economic processes. The role of the state as an organizing principle in the complex process of social evolution is intensified exctly during the periods of increasing instability of the system and a change the modes of interaction between the state and the economy. This requires prevention of the devastating consequences of these processes, which is what President D. Trump's team is engaged in, implementing important economic, political, social and legal reforms.

Thus, under modern conditions, the United States is a locomotive of the world economy and their policy in the field of monetary regulation and credit has a serious impact on the global economy. Trump repeatedly argued that he was in favor of the monetary policy that is currently under control of J. Powell, an American lawyer, Chairman of the Governing Board, who was nominated by the US president on November 2, 2017 and approved by the Senate vote on January 23, 2018. In other times, Trump declared that the Fed created a very unsteady economy and that interest rates should be changed. Trump considers that the way out of this situation is an impossible under any circumstances return to the gold standard, saying:

${ }^{41}$ Law on the Improvement of the Administration of Justice by Establishing an Accountable Administrative Procedure (1946). - URL: http:// static1.1.sqspcdn.com/static/f/276323/26217983/1431377158130/v86_i1_felter. pdf?token=\%2B8c3DRu2JzZAzXCD5tpWAa91\%2B2Q\%3D 
"It would be very difficult to make the gold standard again, but that would be great. We would have a standard to base our money on" ${ }^{2}$.

\section{CONCLUSIONS}

It is obvious that the actions of the White House head in the international arena are governed by internal political calculations, and not by considerations peculiar to political realism. And although the 45th head of the United States professes certain principles that bring him closer to realists, but this is more a matter of purely theoretical ideas.

Many of the positions of Trump's economic program, which contradict the fundamentals of globalization, are contradictory. Some of them are just hard to do. Indeed, the basis of globalization lies in quite objective reasons: it is impossible to cancel the internationalization and transnationalization of production by any decrees and privileges. In a market economy, capital goes where the norm or mass of profit is higher.

All this occurs in the conditions of the sharpest political struggle. Obviously, Trump is not accepted, and it is not known whether the US political class will accept it as the country's leader. The deep contradictions of his economic policy are sometimes not even discussed against the background of endless mutual recriminations and accusations. There is a political crisis, which is not the best condition for the implementation of economic plans and reforms

Among American voters, the reform of financial regulation remains extremely popular. However, the state policy pendulum changes direction in the direction of deregulating the financial sector. Nevertheless, a full return to the pre-crisis level of regulation is not expected, as the Republicans are aware of the cyclical nature of financial and economic development. Trump's policy e shows that the United States is not going to cede leadership positions in international financial regulation.

${ }^{42}$ Groppe M. President Trump's Budget Reveals His Major Priorities: Here are the Highlights. - 2017. - URL: https://www.usatoday.com/story/news/ politics/2017/05/23 president-trump-budget-reveals-his-major-priorities/102058 690/ 
Finally, it can be concluded that D. Trump's controversial statelaw policy in the foreign arena and within his own country is a necessary but correct answer to the problems that have arisen in connection with the globalization crisis.

\section{SUMMARY}

The given article deals with specific features of state formation and legal policy of president D. Trump. Main features of D. Trump's foreign policy are analyzed. The specific attention to the international legal traditions in the area of defending human rights and freedoms is constantly heated by the resolutions of the Supreme Court of the USA are paid. Legal principles of economic policy of D. Trump are investigated. "New financial policy" of president Trump is developed. The main organizational and legal peculiarities of financial activity are discovered. Among them the following: 1) it differs from other spheres of the state activity by inter-sectoral content, since the accumulation and distribution of financial resources affects all authorities and administrations, as well as corporations, organizations and institutions involved in their implementation; 2) budget funds for the main spheres of life of the state or entities of the American federation are distributed by the representative bodies; 3) The scope of financial activity refers to the behavior of both federal bodies and entities of the American federation and local selfgoverning bodies.

\section{REFERENCES}

1. Foundations of Colonial America; a Documentary History : in 3 vols. / ed. by W. K. Kavenagh. - N. Y.: Chelsea House Publishers, 1973. - Vol. 1. - P. 45-49.

2. Schlesinger A.M. The Cycles of American History. - N.Y.: Houghton Mifflin Harcourt, 1999. - P. 34.

3. Hartz L. The Liberal Tradition in America. - Eugene; Oregon: Harvest Books, 1991. - P. 5.

4. American Philosophical Society, Library. Weedon George Henry (1730-1790), General Military Correspondence and Other Materials. - № 131, 139. 
5. Universal Declaration of Human Rights. United Nations // URL: https://www.un.org/en/udhrbook/pdf/udhr_booklet_en_web.pdf

6. Glendon M.A. A World Made New: Eleanor Roosevelt and the Universal Declaration of Human Rights. - N.Y.: Random House Trade Paperbacks, 2001. - P. 4-5.

7. Stacy L., Gardiner Ch.L. Criminal Justice Policy. - 2013 / [Text]. - URL: https://play.google.com/store/books/details/ Stacy_L_Mallicoat_Criminal_Justice_Policy?id=nhlzAwAAQBAJ

8. The Judiciary Act of 1789. - URL: http: //www. constitution.org/uslaw/judiciary_1789.htm

9. Human Rights. - URL: https: // www.state.gov/j/drl/hr/

10. Human Rights and United States Law. - URL: http:// www.theadvocatesforhumanrights.org/human_rights_and_the_united _states

11. U.S. Withdraws from U.N. Human Rights Council Over Perceived Bias Against Israel. - URL: https://www. washingtonpost.com/world/national-security/us-expected-to-backaway-from-un-human-rights-council/2018/06/19/ a49c2d0c-733c11e8-b4b7-308400242c2e_story. html?utm_term=.358873b15730

12. American Philosophical Society, Library. Calendar of the Papers of Benjamin Franklin. - Vol. 1. - Film 54. - Reel 43, 107, 113; American Philosophical Society, Library. Presidential Papers Microfilms. Thomas Jefferson Papers. Jeneral Correspondence, 1761-1826. Account Books for the Years 1767-1770. Reel 58, Serie 4; Reel 59, Serie 4-5; Reel 60, Serie 11-12.

13. NCAI Denounces President Trump's Invoking of Wounded Knee Massacre and Battle of Little Bighorn in Political Attack. URL. - Режим доступу: http://www.ncai.org/news/articles/ 2019/01/14/ncai-denounces-president-trump-s-invoking-of-woundedknee-massacre-and-battle-of-little-bighorn-in-political-attack

14. Duignan B. Donald Trump President of the United States. URL: https://www.britannica.com/ biography/Donald-Trump

15. Калашников В. М., Малишко В.М. Формування інститутів держави і права в США ранньої доби (1607-1775 роки). Монографія. - К.: Логос, 2015. - С. 9. 
16. Кущ О. Проблемы индейцев шерифа не волнуют: Зачем США вводят пошлины против таких стран, как Украина. - URL: https:// 112.ua/ mnenie/problemy-indeycev-sherifa-ne-volnuyutzachem-ssha-vvodyat-poshliny-protiv-takih-stran-kak-ukraina444994.html

17. Statement By U.S. Trade Representative Robert Lighthizer on Section 301 Action. - URL: https://ustr.gov/about-us/policyoffices/press-office/press-releases/2018/ august/state ment-us-traderepresentative

18. The Constitution of the United States. The Bill of Rights \& All Amendments. - URL: https://constitutionus.com

19. Oliver W.M. The Power to Persuade: Presidential Influence over Congress on Crime Control Policy // Criminal Justice Review. 2003. - N 28. - P. 113-132.

20. U.S. Code: Title 18. - Crime and Criminal Procedure. - URL: //www/ law/cornell/edu/uscode/text/18.

21. Settel A. Pictorial History of the United States Customs Service. - N.Y.: Crown Publications, 1976. - P. 10.

22. Уголовное законодательство зарубежных стран (Англии, США, Франции, Германии, Японии). Сборник законодательных материалов / [Текст] / [под ред. И. Д. Козочкина]. - М.: Зерцало, 1999. $-352 \mathrm{c}$.

23. U.S. Code: Table Of Contents. Legal Information Institute. URL: https://www.law.cornell.edu/uscode/text

24. Model Penal Code. The American Law Institution. 6th Annual Meeting. May 20-22, 2019. - Washington, DC/ [Text]. - URL: https://www.ali.org/ publications/show/model-penal-code/

25. President Donald Trump Hit Chinese Smports to the US with Massive Tariffs on Thursday. - URL: https:// www.businessinsider.com/trump-tariffs-what-is-a-tariff-meaning-forprices-consu mer-2018-3.

26. Electronic Code of Federal Regulations. - URL: http://www.ecfr. gov/cgi-bin/ECFR?page=browse.

27. Rocha A.F. And Up to Twenty Years in Prison: The Criminalization of US Customs Violations - July 2015 [A.F. Rocha, D. Barclay, D. Bond, D. Lew, G. Spak, L. Winer]. - P. 10. - 
URL: https: //wwwgfintegrity.org/wp-content/uploads/2015/07/ Criminalization-of-US.29.

28. Report of the Subcommittee on Criminal Justice on Recodification of Federal Criminal Law. Subcommittee on Criminal Justice of the Committee on the Judiciary, House of Representatives. Ninety-fifth Congress, Second Session. - Wash.: U.S. Government. Print. Off., 1979. - P. 11.

29. Brown M. The Criminalization of Import Violations by Customs Authorities. - P. 21-22. - URL: https: //www.mayerbrown.com/public_docs/07-13-11_GlobalStrategiesCriminalization_of_Import.pdfp.

30. Катасонов В.Ю. Диктатура банкократии. Оргпреступность фанансово-банковского мира. Как противостоять финансовой кабале. -2014. - URL: https://www.ozon.ru/context/detail/id/2765 $5786 /$

31. Calabria M.A. Monetary History and Policy. A Reading List [M.A. Calabria, J.A. Dorn, G. Selgin]. - URL: https://www.cato.org/ research/banking/rl-monetary-policy.html

32. The U.S. Financial Regulatory System. URL:https://www.cfr.org/backgrounder/us-financial-regulatorysystem

33. Долан Э. Дж., Кэмпбелл Р. Дж. Деньги, банки и денежнокредитная политика: [пер. с англ.]. - СПб.: АОЗТ «Литера плюс», 1994. - URL: http://www.bibliotekar.ru /bank-8/

34. What Impact Does Government Regulation Have on the Financial Services sector? Updated Feb 5, 2018. - URL: https://www. investopedia.com/ask/answers/030315/what-impact-doesgovernment-regulation-have-financial-services-sector.aspl

35. Wildavsky A. The Politics of the Budgetary Process. - Boston; Toronto: Little Brown Co., 1964. - P. VI-VII.

36. Glaeser E.L., Goldin C.D. Corruption and Reform: Lessons from America's Economic History. - Chicago: University of Chicago Press. - URL: http://bookre.org/reader?file=711219

37. GC18/1: Proposed Guidance on Financial Crime Systems and Controls: Insider Dealing and Market Manipulation. Guidance consultations. First published: 27/03/2018. Last updated: 
27/03/2018.- URL: https://www.fca.org.uk/ publications/guidanceconsultations/gc18-1-proposed- guidance-financial-crime-systemsand-controls-insider-dealing

38. Federal Policy on Financial Regulation, 2017-2020. - URL: https: I/ ballotpedia.org/Federal_policy_on_financial_ regulation,_2017-2020

39. Federal Reserve Act. Section 2 A: Monetary policy // The Board of Governors of the Federal Reserve System: website. 2013. May 23. - URL: http://www.federal reserve.gov/aboutthefed/ section2a.htm.

40. A Financial System That Creates Economic Opportunities. Banks and Credit Unions. U.S. Department of the Treasury. Report to President Donald J. Trump. Executive Order 13772 on Core Principles for Regulating the United States Financial System. June 2017. - URL: https://www.treasury.gov/press-center/press-releases/ Documents/A\%20Financial\%20System.pdf Financial

41. Law on the Improvement of the Administration of Justice by Establishing an Accountable Administrative Procedure (1946). URL: http:// static1.1.sqspcdn.com/static/f/276323/26217983/ 1431377158130/v86_i1_felter.pdf?token=\%2B8c3DRu2JzZAz XCD5tpWAa91\%2B2Q\%3D

42. Groppe M. President Trump's Budget Reveals His Major Priorities: Here are the Highlights. - 2017. - URL: https://www.usatoday.com/story/news/ politics/2017/05/23presidenttrump-budget-reveals-his-major-priorities/102058 690/

\section{Information about the author:}

Kalashnikov V. M.,

Ph.D., Doctor of Historical Sciences, Professor, Professor of the Theory of State and Law, Constitutional Law and

State Government Department Oles Honchar Dnipro National University 72, Haharin av., Dnipro, Ukraine 